\title{
O REGIME INTERNACIONAL DE MUDANÇA CLIMÁTICA E O BRASIL
}

\author{
Eduardo Viola
}

Este artigo é constituído de três partes. Na primeira, analisa-se o processo de formação do regime internacional de mudança climática, desde as negociações e a assinatura da convenção Quadro das Nações Unidas sobre Mudança Climática, no Rio de Janeiro (1992), passando pela negociação e a assinatura do Protocolo de Kyoto (1997), até a conclusão das questões pendentes do Protocolo na VII Conferência das Partes (COP), em Marrakesh (2001).

$\mathrm{Na}$ segunda, analisam-se as políticas públicas relacionadas às emissões de carbono no Brasil, na década de 1990, e o posicionamento brasileiro quanto ao regime de mudança climática. O Brasil teve uma posição de liderança no processo de negociação da Convenção de Mudança Climática (1990-1992), pois sua política externa se afastava da posição desenvolvimentista radical predominante até 1988. Durante Protocolo de Kyoto (1996-2001), o país se opôs a compromissos de redução da taxa de crescimento futuro das emis- sões de carbono por parte dos países emergentes, ao estabelecimento de mecanismos flexibilizadores de mercado e à inclusão das emissões derivadas de mudança do uso da terra. Em maio de 1997, o Brasil fez uma proposta original: a criação de um Fundo de Desenvolvimento Limpo (FDL), que aplicaria multas aos países desenvolvidos que não cumprissem as metas de redução de emissões. A proposta foi apoiada pelos países em desenvolvimento e rejeitada pelos países desenvolvidos. Em outubro de 1997, os Estados Unidos e o Brasil elaboraram uma nova versão do FDL, que passou a ser chamado de Mecanismo de Desenvolvimento Limpo (MDL). O MDL criou a possibilidade de os países desenvolvidos cumprirem parte de suas metas de redução de emissão condicionada ao financiamento de projetos de desenvolvimento sustentável nos países em desenvolvimento.

$\mathrm{Na}$ terceira parte, analisam-se as perspectivas futuras do Protocolo de Kyoto depois dos acordos nas convenções de Bonn e Marrakesh, particular- 
mente em relação à sua viabilidade com a ausência dos Estados Unidos.

\section{A Formação do regime internacional de mudança climática}

O regime de Mudança Climática é um dos mais complexos e relevantes regimes internacionais porque implica profundas inter-relações entre a economia e o ambiente global. Os principais instrumentos do regime são a convenção Quadro das Nações Unidas sobre Mudança Climática, assinada no Rio de Janeiro em junho de 1992, e o Protocolo de Kyoto, assinado em Kyoto em dezembro de 1997. Um dos problemas fundamentais da viabilidade desse Protocolo deriva do fato de ele ter sido aprovado no interior de uma negociação extremamente difícil e emergencial. Além disso, vários artigos-chave ficaram em suspenso, devendo ser discutidos em uma conferência posterior. Desde a IV Conferência das Partes, realizada em Buenos Aires, em 1998, até a VI, em Haia, em 2000, tem predominado um impasse na negociação dessas questões pendentes. O Protocolo de Kyoto dividiu os países em dois grupos: os pertencentes (membros da OECD e países do ex-bloco comunista do Leste Europeu) e os não pertencentes ao Anexo Um. Os do primeiro grupo, ao contrário dos do segundo, têm compromissos obrigatórios de emissões máximas para o ano 2010, ainda que os do segundo grupo possam tê-los em data posterior a esta.

Os problemas ambientais globais, juntamente com a revolução da informação e a globalização econômica, contribuíram para alterar as relações entre os Estados (North, 1990; Haas, Keohane e Levy, 1993; Hurrell, 1995; Haas, 1997). Para compreender a complexidade desses problemas é necessário não se restringir aos principais enfoques teóricos das relações internacionais - neo-realismo e institucionalismo liberal - e analisar quatro dimensões de clivagem e alinhamento - interestatal, civilizatória, democracia versus não-democracia, e dentro da democracia, liberalismo versus comunitarismo.

$\mathrm{Na}$ primeira dimensão, a clássica clivagem entre os Estados nacionais continua sendo uma fonte essencial de competição e cooperação, com diminuição do conflito e aumento da cooperação (comparado com o período da Guerra Fria), devido à intensificação da interdependência econômica e tecnológica. $\mathrm{Na}$ ordem interestatal, os Estados Unidos ocupam uma posição de superpotência, sendo considerados hiperpotência militar e, economicamente, compartilham a centralidade com a União Européia e o Japão. Em seguida, têm-se as potências regionais: Rússia, China, Índia e Brasil. Pelo critério da eficácia e da eficiência de governabilidade, os Estados podem ser classificados como: desenvolvidos, emergentes, semifracassados e fracassados. A ordem interestatal é fundamental ao se analisar os problemas ambientais globais, na medida em que são os Estados as partes contratantes nos regimes internacionais.

Na segunda, observa-se uma diferenciação entre as grandes civilizações, cuja obra de Huntington tornou-se referência fundamental, a saber: ocidental, latino-americana, eslava, japonesa, confuciana, islâmica, hinduísta e africana. A civilização ocidental representa o que poderíamos chamar de "vanguarda do processo civilizatório", pois a integração de elementos como economia de mercado, individualismo, Estado de direito e democracia representativa produziram uma sociedade "superior" quanto ao domínio da natureza e à construção de uma tecnosfera. A civilização japonesa já segue plenamente o modelo ocidental. A civilização latino-americana é, atualmente, bastante heterogênea - países como Chile, Costa Rica, Uruguai, Brasil e México se alinham com a civilização ocidental e, em outro extremo, observa-se uma grande distância, no caso de Cuba, Haiti, Nicarágua, Guatemala e Honduras. A civilização eslava somente em 1989 iniciou o processo de aproximação com o Ocidente, contando com avanços e retrocessos. A civilização confuciana tende, de um lado, a uma convergência com o Ocidente em virtude do vetor tecnológico e, de outro, a um distanciamento em virtude do vetor sociopsicológico. A civilização hinduísta mantém-se muito distante da ocidental, na medida em que conserva o regime de castas, mas aproxima-se em virtude do vetor tecnológico e da democracia política. A civilização islâmi- 
ca vive atualmente um processo de confronto com a civilização ocidental e, em menor grau, com as civilizações hinduísta, eslava e chinesa. A civilização africana depois de ter sido parcialmente ocidentalizada durante o período colonial de meados do século XIX a meados do século XX encontra-se em processo de regressão. A civilização ocidental foi, na década de 1960, o berço do moderno ambientalismo. A partir de então, houve uma expansão da discussão dos problemas ambientais para a civilização japonesa, na década de 1970, e para a latino-americana, na década de 1980 até hoje.

$\mathrm{Na}$ terceira, tem-se a clivagem entre o mundo democrático (enraizado nas civilizações ocidental e japonesa, quase consolidado em alguns países da civilização latino-americana, mas ainda frágil em outros e nas civilizações hinduísta e eslava) e o mundo não-democrático (a maior parte das civilizações chinesa, islâmica e africana). Com exceção de Singapura, pode-se constatar uma forte relação entre democracia e expansão da preocupação pelos problemas ambientais.

$\mathrm{Na}$ quarta, tem-se a clivagem entre liberalismo e comunitarismo no interior do mundo democrático. O liberalismo é a corrente dominante em todo o mundo democrático (exceto Japão) e baseia-se no domínio do indivíduo sobre os grupos, do mercado sobre a política, na meritocracia e na representação política com participação esporádica através de partidos. O comunitarismo é uma corrente secundária no mundo democrático (exceto no Japão, onde predomina) e apresenta períodos de grande avanço, como na rebelião estudantil de 1968, na utopia da governabilidade por meio da sociedade civil mundial logo depois da Guerra Fria e no movimento antiglobalização de Seattle em Porto Alegre. Baseia-se no predomínio do grupo sobre o indivíduo, da política sobre o mercado (nas formas mais extremadas há rejeição ao mercado) e na alta participação política por meio de múltiplas estruturas associativas que podem ser mais adscritivas ou mais baseadas nas opções construídas individualmente. O ambientalismo moderno originou-se na vertente comunitária da democracia, mas com o passar do tempo, uma parte importante dele se converteu à vertente liberal.
Se até a década de 1970 todos os Estados importantes, agindo em interesse próprio, eram capazes de solucionar, seja pela conciliação, seja pela imposição, a maioria de suas disputas com outros Estados sem prejuízo de sua soberania, a partir da década de 1980 ocorreu uma perda diferenciada de autonomia de quase todos eles (com a única exceção dos Estados Unidos) e uma necessidade cada vez maior de cooperação internacional, o que exige muita flexibilidade nas negociações. O benefício coletivo exige cada vez mais ações que contrariam os interesses de cada Estado individual. A formação de regimes internacionais econômicos, de segurança e ambientais passa a impor algumas restrições à soberania da grande maioria dos Estados (Chayes e Handler Chayes, 1995; Keohane e Miller, 1996). Existe, ao mesmo tempo, uma certa transferência de poder do Estado para instituições supranacionais que vão constituindo novos centros de autoridade e para corporações transnacionais (Risse-Kappen, 1995; Comission on Global Governance, 1995; Castells, 1996; Rosenau, 1997; Keck e Sikkink, 1998).

Os problemas de mudança climática estão vinculados aos bens comuns/coletivos globais (Kaul, Grunberg e Stern, 1999). A atmosfera, por exemplo, é um bem público global, desde que sua utilização por um ator não exclua a possibilidade de utilização por outro. Ela tem, no entanto, uma capacidade limitada em absorver poluição ou emissões de gases de efeito estufa sem provocar alterações na saúde humana ou no clima. Em vista dessa limitação, as cúpulas e as convenções internacionais da última década atribuíram à atmosfera o estatuto de "preocupação comum da humanidade", e os problemas do seu uso foram consensualmente vinculados à construção de regimes internacionais (McCormick, 1989).

Existem duas concepções gerais sobre os regimes ambientais internacionais: uma formal (sentido estrito) e outra substantiva (sentido amplo) (Krasner, 1983; Keohane, 1983; Porter e Brown, 1996; Hurrell, 1995; Soroos, 1997). De acordo com ambas as concepções, tais regimes são um sistema de regras, explicitadas num tratado internacional pactuado entre governos, que regulam as ações dos diversos atores sobre o as- 
sunto. Contudo, a visão mais abrangente também considera os regimes ambientais um vetor tecnológico e cultural em desenvolvimento favorável à proteção de um bem coletivo global (Sand, 1992; Gehring, 1994; Norhaus, 1994; Young, 1997). Ou seja, o regime de mudança climática, segundo esta concepção, não se restringe aos acordos estabelecidos na Convenção do Rio de Janeiro e no Protocolo de Kyoto, mas prevê também a necessidade de uma consciência pública favorável a estabilizar o clima e de um vetor tecnológico que favoreça o investimento em tecnologias não intensivas em carbono. Neste trabalho utilizarei o conceito de regime ambiental internacional em sentido amplo.

A comunidade científica tem um papel-chave em relação a essas questões, pois quando a grande maioria de cientistas concorda no diagnóstico de um problema e é eficiente em comunicálo ao público em geral e aos decisores, cria-se aquilo que denominamos "comunidade epistêmica”, adquirindo, então, peso internacional (Haas, 1992). A constituição do Painel Intergovernamental sobre Mudança do Clima (IPCC), em 1988, deu início ao processo de análise e avaliação dos efeitos da mudança climática que foi traduzido politicamente na constituição do Comitê Negociador Internacional (INC) para uma Convenção sobre Mudança do Clima. Durante toda a década de 1990, o IPCC forneceu subsídios fundamentais para a condução das negociações no âmbito da Convenção e tem assumido um papel de referência na formação da opinião pública internacional sobre a questão da mudança climática. O último relatório do IPCC (janeiro de 2001) estabeleceu o fim da incerteza científica prévia sobre a mudança climática. A temperatura média da Terra poderá subir de 1,5 grau até 6 graus, até o ano 2100, com impactos gigantescos sobre os ecossistemas naturais, a agricultura, as estruturas urbanas, as regiões costeiras e a saúde humana. Fenômenos climáticos locais/regionais extremos (secas mais fortes e prolongadas, ondas de calor mais intensas, inundações mais severas, tormentas e furacões mais fortes) já ocorrem com mais freqüência desde meados da década de 1990. Os países, em geral, têm sofrido com essas alterações: aumento de mortalidade nos países de renda baixa (enchentes na África Austral e Norte da Índia, furacões em Bangladesh e América Central, seca na Ásia Central etc.), destruição de patrimônio em países de renda alta (tormentas e enchentes na Europa Ocidental, seca no Meio Oeste e queimadas no Oeste dos Estados Unidos etc.), prejuízos semelhantes em graus variáveis nos países de renda média (enchentes na Venezuela e na província de Buenos Aires etc.).

A comunidade científica dos climatólogos, que durante a década de 1980 formulou a teoria do aquecimento global, é constituída em aproximadamente dois terços por cientistas que trabalham em instituições norte-americanas. Os Estados Unidos, sob a recém-iniciada presidência de Bush, assumiu um papel de liderança nas negociações que levaram à formação do Painel Intergovernamental sobre Mudança do Clima (IPCC) e à convocação da UNCED, em 1989 (Weiss Brown e Jakobson, 1998). Durante a campanha eleitoral de 1988, Bush tinha-se distanciado de Reagan, afirmando que o aquecimento global seria uma das grandes prioridades de seu governo. Travouse uma disputa interna entre duas facções do governo: os globalistas, liderados por William Reilly, diretor da Environmental Protection Agency (equivalente ao cargo de ministro do meio ambiente), e os conservadores, liderados por John Sununu, chefe da Casa Civil. Desde meados de 1988 (verão mais quente do século no país) até julho de 1990, a questão do aquecimento global ocupou uma posição destacada em todas as pesquisas de opinião pública. A invasão do Kuwait pelo Iraque, em agosto de 1990, e a subseqüente Guerra do Golfo desviaram a atenção e arrefeceram as opiniões pró-ambiente dos norte-americanos. A crise do Golfo mostrou claramente a intensa dependência do petróleo da economia norte-americana. Além disso, ficou evidente que a economia norteamericana é "carbono intensiva", ou seja, metade da energia elétrica é produzida a partir de termoeléctricas que queimam principalmente carvão e, secundariamente, petróleo; outra metade é produzida por usinas hidroelétricas, nucleares, termoeléctricas de gás natural e, de maneira reduzida, por usinas eólicas; o automóvel individual (de tamanho médio maior que no resto do mundo) é o 
meio generalizado de transporte de passageiros. Diminuir as emissões de carbono teria custos significativos em curto prazo. Entre o medo de uma mudança climática incerta e num futuro distante e a perspectiva imediata de queda no padrão de vida material, a maioria dos norte-americanos inclinou-se em favor da manutenção de seu padrão.

Essa mudança teve reflexos imediatos no interior do governo Bush. A partir de agosto de 1990, os conservadores triunfaram em relação aos globalistas. Nos PREPCOMS que negociaram a convenção de mudança climática nos anos de 1990-1992, a posição norte-americana foi cada vez mais contrária ao estabelecimento de metas de redução da emissão de gases de efeito estufa, com o argumento de que havia muitas incertezas a respeito do assunto e que, portanto, era necessário uma maior investigação científica; e cada vez mais favorável à promoção de sumidouros de carbono por meio da plantação maciça de florestas. Apenas os países escandinavos, a Holanda e a Alemanha tinham posições definidas em favor de estabelecer metas obrigatórias de redução (Rowlands, 1995; O'Riordan, 1996). O texto final da United Nations Framework Convention on Climate Change (UNFCCC) estabeleceu um compromisso genérico para os países pertencentes ao Anexo Um: o ano base das emissões seria 1990 e, em 2000, as emissões desses países não deveriam ser superiores as de 1990. Para os países não pertencentes ao anexo, a convenção estabeleceu o compromisso de se elaborar inventários nacionais de emissões de carbono.

Durante a campanha eleitoral de 1992, logo depois da Conferência realizada no Rio de Janeiro, Clinton e Gore articularam uma posição claramente globalista e prometeram, aproveitando o impulso favorável da opinião pública norte-americana, uma ação firme e de liderança para enfrentar o problema do aquecimento global. Na I Conferência das Partes da Convenção de Mudança Climática (Berlim, março de 1995), o governo Clinton assumiu uma posição de liderança no sentido de estabelecer metas obrigatórias de redução para os países desenvolvidos e metas de redução da taxa de crescimento futuro das emissões para os países emergentes. O Brasil teve, nessa con- venção, um papel importante ao argumentar que, numa primeira fase, não seria apropriado o estabelecimento de compromissos por parte dos países em desenvolvimento, e, durante a discussão, conseguiu o apoio do Japão e de vários países europeus, o que isolou a posição norte-americana em relação a esta questão. Na II Conferência das Partes (Genebra, 1996), a delegação norte-americana liderada pelo subsecretário de Estado para Assuntos Globais, Tim Wirth (senador ambientalista de Colorado), afirmou novamente a urgência de se negociar metas obrigatórias de redução de emissões de efeito estufa, introduzindo, pela primeira vez, a idéia de cotas comercializáveis de emissão de carbono, que serviriam como um mecanismo flexibilizador complementar na redução de emissões entre os países do Anexo Um (Grubb, 1999). Esta idéia baseava-se na experiência com as cotas comercializáveis de emissão de enxofre e material particulado entre as usinas elétricas por bacias aéreas (Milner, 1997), implementada há quatro anos no país e que tinha se mostrado muito mais efetiva do que os clássicos mecanismos de comando e controle na redução de emissões. A proposta de Wirth foi, em termos gerais, rejeitada por três razões: primeiro, em virtude da falta de compreensão do modelo, já que nenhum outro país havia experimentado tal mecanismo; segundo, havia um princípio contra o uso de mecanismos de mercado para a proteção ambiental; terceiro, porque a proposta norte-americana incluía compromissos por parte dos países emergentes de reduzir a taxa de crescimento das emissões. Finalmente, a COP II concordou em iniciar imediatamente as negociações para estabelecer um Protocolo que tornaria obrigatória a redução de emissões por parte dos países pertencentes ao Anexo Um, e que tentaria estudar formas de estabelecer mecanismos complementares.

Entre a segunda e terceira conferência das Partes (Genebra, junho de 1996, e Kyoto, dezembro de 1997) houve uma série de negociações para a formulação do Protocolo de Kyoto. A posição norte-americana seguiu três linhas principais: o estabelecimento de metas baixas (menos de 5\%) de redução de emissões até 2010, tendo como ano base 1990; o estabelecimento de metas de redu- 
ção da taxa de crescimento das emissões por parte dos países emergentes; e o estabelecimento de mecanismos de mercado que flexibilizassem as metas, particularmente as cotas comercializáveis de emissão entre os países do Anexo Um. Quanto à primeira meta, os Estados Unidos obtiveram sucesso em relação aos europeus, que queriam compromissos de redução mais contundentes. Quanto à segunda, foram derrotados, como já haviam sido nas conferências de Berlim e Genebra. Em relação à terceira, condicionaram a assinatura do acordo ao compromisso de flexibilização, contando com forte apoio do Canadá, da Austrália, da Rússia e dos países do Leste Europeu, membros do Anexo Um (Cooper, 1998).

Em julho de 1997, durante a negociação do Protocolo de Kyoto, o Senado norte-americano, com maioria republicana, posicionou-se contrário à ratificação do protocolo, a menos que os países emergentes assumissem compromissos de diminuir sua taxa de crescimento futuro de emissões (Agrawala e Steinar, 1999). Apesar disso, o governo Clinton assinou o protocolo, mas não o enviou ao Senado para ratificação. Começou, entretanto, a articular politicamente no sentido de obter os compromissos de atenuação no crescimento das emissões por parte de alguns países emergenteschave (Lippman, 2000; Jacoby e Primm, 1998). A diplomacia norte-americana foi bem-sucedida somente em relação à Argentina e à Coréia do Sul.

O regime de mudança climática exige sempre a presença de pelo menos um ator que impulsione o processo e que seja capaz de liderar e sustentar o regime. Pela sua importância na economia e no ambiente global e pela eficiência de sua governabilidade, apenas três países apresentam este potencial em primeira instância (Estados Unidos, União Européia e Japão). O Estado Europeu supranacional, neste caso, tem uma capacidade de atuação muito maior do que os Estados nacionais. Países como China, Índia, Rússia, Canadá, Indonésia e Brasil têm se revelado muito importantes em todo o processo de decisão, apesar de não constituírem um potencial de liderança (Grubb, 1999). Enfim, a participação desses nove países é condição básica para o funcionamento do regime de controle de emissões. Os dados, a seguir, são indicadores econômicos desses países:
- Proporção na população mundial (1999): China 21\%, Índia 16,5\%, União Européia 6,3\%, Estados Unidos 4,6\%, Indonésia 3,5\%, Brasil 2,8\%, Rússia 2,4\% e Japão 2,1\%.

- Proporção na parcela do PIB mundial (por poder de compra, em 1999): Estados Unidos $21,3 \%$, União Européia 20,5\%, China 10,2\%, Japão 8\%, Índia 5,4\%, Brasil 2,9\%, Rússia 2,4\%, Canadá 2,3\%, Indonésia 1,3\%.

- PIB per capita (poder de compra em 1999): Canadá 31.000 dólares, Estados Unidos 29.200 dólares, União Européia 24.000 dólares, Japão 23.600, Brasil 6.500, Rússia 6.200, China 3.100, Indonésia 2.400 e Índia 2.100.

- Parcela nas emissões mundiais de carbono (1999): Estados Unidos 24,5\%, União Européia 14,5\%, China 13,5\%, Japão 6\%, Rússia 5\%, Índia 4,5\%, Canadá 2,5\%, Brasil 2,5\% e Indonésia 1,5\%.

- Parcela da área florestal mundial (1995): Rússia 22\%, Brasil 16\%, Estados Unidos 6\%, Canadá $5 \%$, China 4\%, Indonésia 3\%, União Européia $2 \%$, Índia $2 \%$, Japão $0,7 \%$.

- Taxa de desmatamento médio anual (19901998): Indonésia 1,1\%, Brasil 0,5\%, China 0,1\%, Rússia $0,1 \%$, Índia 0,05\%, União Européia 0\%, Japão 0\%, Canadá 0\%, Estados Unidos aumenta sua área com florestas 0,3\% ao ano.

Os Estados Unidos, como se pode observar, é o único país que está incrementando anualmente uma área florestada e, por isso, tem defendido a inclusão dos sumidouros de carbono no cálculo total de emissões (Brown, Flavin e French, 2001).

Os conflitos de interesse entre os países desenvolvidos, emergentes e pobres é um dos fatores determinantes na dinâmica das negociações no processo de estabelecimento do regime de mudança climática (Young, 1997; Claussen e McNeilly, 1998; Mueller, 1999). Nas democracias existe uma forte disputa interna de interesses e de valores, o que faz com que a posição de um país num momento específico da negociação resulte de uma coalizão que oscila de acordo coma definição da política do país no cenário internacional. As alianças e os blocos que se formaram desde 
a Conferência no Rio de Janeiro, em 1992, resultaram de disputas acirradas entre os países, de clivagens e de alinhamentos nacionais, internacionais e transnacionais (Viola, 1998). O regime de mudança climática foi liderado pelos Estados Unidos e pela União Européia entre 1989 e 1991; pela União Européia entre 1991 e 1995; pelos Estados Unidos, União Européia e Japão entre 1995 e 1997; e, desde 1998, apenas pela União Européia. Os principais blocos formados (desde 1992) são (Clark, Van Eijndoven e Jaeger, 1998; Soroos, 1997; Vogler e Imbler, 1996; Wasson, 1997; Schelling, 1997):

- Países desenvolvidos com alta intensidade de carbono por unidade de PIB e per capita (Estados Unidos, Canadá e Austrália). Nesses países, ocorre uma divisão de forças clara entre, de um lado, neoliberais e nacionalistas - contrários ao regime de mudança climática -, e, de outro, neosocialdemocratas e verdes - respectivamente, favoráveis de maneira moderada ao regime e fortemente favoráveis ao regime (Inglehart 1997). Os Estados Unidos encontram-se numa posição delicada, pois sua taxa de emissão de carbono em 1999 foi 14\% superior à de 1990 (ano base para todos os países), e o compromisso assumido em Kyoto é diminuir 7\% até 2010. No Canadá há uma defasagem similar.

- Países desenvolvidos com média intensidade de carbono por unidade de PIB e per capita, orientados a assumir responsabilidades globais (Alemanha, Reino Unido, Holanda, Suécia, Dinamarca, Finlândia, França, Bélgica, Luxemburgo, Áustria e Itália). Nesses países predominam os neosocialdemocratas, fortemente favoráveis ao regime de mudança climática (Guidens 1998). Também os verdes constituem uma minoria forte, que pressiona no sentido de fortalecer o regime. O restante da União Européia (Espanha, Portugal, Grécia e Irlanda), embora tenha populações menos dispostas à redução de emissão, apóia a posição dos primeiros devido às compensações recebidas dentro da União. Reino Unido, Alemanha, Dinamarca e Suécia são os únicos países do Anexo Um que tinham, em 1999, emissões compatíveis a atingir os compromissos estabelecidos para 2010.
- Países desenvolvidos com média intensidade de carbono, que têm dificuldades em reduzir sua emissão, seja porque já haviam reduzido bastante suas taxas antes de 1990 (Japão, Nova Zelândia, Noruega), seja porque possuam uma opinião pública com baixa responsabilidade global (Suíça, Islândia). O Japão assumiu o compromisso de reduzir as emissões em $6 \%$ até 2010, mas, em 1999, apresentou uma taxa 4\% mais altas.

- Países pertencentes à ex-União Soviética que sofreram uma drástica redução nas emissões de carbono (entre 40\% e 60\% mais baixas, em 1999, comparadas com 1990) pelo colapso da economia (Rússia, Ucrânia, Bielo-rússia, Bulgária, Romênia) e, em conseqüência, têm créditos no conjunto de compromissos assumidos. Nessas sociedades, predominam os nacionalistas ou neoliberais com posições favoráveis ao regime de mudança climática desde que seus respectivos países sejam favorecidos a médio prazo (até 2010/2020, aproximadamente) por meio do mecanismo de comércio de cotas, mas não apóiam políticas públicas nacionais que pretendam diminuir a intensidade de carbono de suas economias, muito alta por unidade de PIB. Já os neosocialdemocratas, presença minoritária com relativa força na Rússia, na Ucrânia e na Romênia, são favoráveis a políticas orientadas a diminuir moderadamente a intensidade em carbono da economia.

- Países exportadores de petróleo (Arábia Saudita, Kuwait, Irã, Iraque, Emirados Árabes, Argélia, Líbia, Venezuela, Indonésia e Nigéria), com alta intensidade de carbono por unidade de PIB e alguns também per capita. Nesses países predominam os neoliberais, os nacionalistas, ou as coalizões entre estas facções, com posições neutras ou contrárias ao regime de mudança climática. Em algumas sociedades, como na Venezuela, constitui uma força política importante a presença minoritária dos neosocialdemocratas, que apóiam moderadamente o regime.

- Países emergentes com média intensidade de carbono por unidade de PIB derivada da matriz energética predominantemente de carvão e/ou 
petróleo (China, Índia, África do Sul e México) ou do excessivo desmatamento (Brasil, Tailândia, Malásia e Filipinas). Esses países, como um todo, apóiam os compromissos firmados no Protocolo de Kyoto em função dos benefícios imediatos advindos da implementação do Mecanismo de Desenvolvimento Limpo. No entanto, há diferenças de opinião entre os países-chave deste grupo. Na China e na Índia predominam as coalizões entre nacionalistas e neoliberais, contrários a assumir os compromissos de limitação das emissões de carbono até aproximadamente 2030. Eles são favoráveis ao regime somente em virtude da perspectiva de ganho com a implementação do Mecanismo de Desenvolvimento Limpo. Contudo, na Índia, por exemplo, existem fortes minorias verdes, favoráveis ao adensamento do regime de mudança climática. No Brasil e no México predominam coalizões entre neosocialdemocratas e neoliberais (com apoio de setores nacionalistas), moderadamente favoráveis ao regime. No Brasil, em particular, há uma importante minoria verde favorável a uma diminuição drástica do desmatamento na Amazônia (responsável por, aproximadamente, 1,8\% das emissões globais de carbono, ao passo que o restante da economia brasileira produz apenas 0,7\% das emissões globais), a assumir compromissos voluntários de redução da taxa de crescimento futuro das emissões e a adensar o regime de mudança climática.

- Países emergentes com baixa intensidade de carbono (Argentina, Chile, Uruguai, Costa Rica, Coréia do Sul e Hungria). Igualmente ao grupo anterior, existe um apoio genérico ao Protocolo de Kyoto, em função do MDL. Nesses países, predominam coalizões entre neoliberais e neosocialdemocratas, moderadamente favoráveis ao regime. Além disso, os neosocialdemocratas são favoráveis a compromissos de redução por parte dos países emergentes. Em muitos desses países há uma presença minoritária dos verdes muito ativa que defende o adensamento do regime de mudança climática.

- Países pobres (África subsahariana, Bangladesh, Bolívia, Honduras, Guatemala etc.), onde todos os setores da sociedade são favoráveis ao adensamento do regime tanto porque implica ganhos consideráveis advindos do Mecanismo do Desenvolvimento Limpo quanto porque dificilmente teriam compromissos de redução antes de 2050.

- Pequenos Estados-ilhas (Fiji, Jamaica, Malta etc.), muito vulneráveis à mudança climática e onde o conjunto da sociedade é fortemente favorável ao adensamento do regime.

Durante as conferências das Partes posteriores a Kyoto (Buenos Aires, 1998; Bonn, 1999 e Haia, 2000), houve quatro coalizões principais de negociação: União Européia, Grupo Guarda-chuva (formado pelos países dos grupos 1, 3 e 4), G77/China, formado pelos países dos grupos 5, 6, 7 e 8 (em algumas questões, dois subgrupos divergiram do G77/China - países exportadores de petróleo e países mais pobres), e, por fim, Aliança das Pequenas Ilhas (Viola, 2001).

A seguir, apresentarei um quadro da conjuntura de forças estabelecida entre os grupos durante as conferências de Bonn e Haia.

O Grupo Guarda-chuva deu grande apoio aos mecanismos flexibilizadores (Comércio de Cotas de Emissão e Implementação Conjunta entre os países do Anexo Um, e Mecanismo de Desenvolvimento Limpo entre todos os países), contra a posição da União Européia. No geral, a posição dos países foi bastante variada e, muitas vezes, oportunistas. O Brasil apoiou o Mecanismo de Desenvolvimento Limpo (inclusive porque este mecanismo teve como base uma proposta originalmente brasileira de junho de 1997), alinhandose ao Grupo Guarda-chuva, mas tendeu a limitar a ação do Comercio de Emissões e da Implementação Conjunta, aproximando-se, então, da posição da União Européia.

O Grupo Guarda-chuva apoiou de maneira incisiva a contabilidade de sumidouros de carbono (florestas, manejo do solo etc.) como dedução dos compromissos de redução de emissões, contra a União Européia. Os demais países dividiramse entre os dois grupos, além daqueles que permaneceram em uma posição neutra. O Brasil apoiou a União Européia, mas a maioria dos países latino-americanos se alinhou com o Grupo Guarda-chuva. 
Os países do Grupo Um, apoiados em graus variáveis pelos países dos Grupos 2 e 3, propuseram a necessidade de os países emergentes assumirem compromissos voluntários de redução da taxa de crescimento futuro das emissões, contra os países dos Grupos 5, 6 e 7 (exceto Argentina e Coréia do Sul).

O G77/China e a Aliança de Pequenas Ilhas propuseram um amplo pacote de transferência livre de tecnologias limpas dos países desenvolvidos para os em desenvolvimento, contra os países dos grupos 1, 2 e 3, que mantiveram uma posição mais branda, propondo um pacote mais reduzido. O Brasil exerceu, nesta questão, um papel de liderança.

Os países exportadores de petróleo, liderados pela Arábia Saudita, defenderam a possibilidade de serem compensados pelas eventuais quedas nas receitas de exportação, contra o resto do mundo.

A União Européia propôs um amplo regime de sanção para aqueles que não cumprissem seus compromissos, contra o Grupo Guarda-chuva, que apresentou um regime menos radical (Weiss Brown e Jacobson, 1998). O Brasil, neste caso, apoiou a União Européia.

No final da Conferência de Haia houve certo consenso nas propostas relativas a compromissos voluntários, ao regime de sanções e à transferência de tecnologia que seriam discutidas na VII Conferência das Partes, em novembro de 2001. Os países exportadores de petróleo renderam-se ao resto do mundo na questão das compensações de receitas de exportação, e chegou-se a um acordo próximo da posição do Grupo Guarda-chuva com relação ao papel dos mecanismos flexibilizadores. O ponto que precipitou o fracasso das negociações foi o teto para a contabilidade dos sumidouros de carbono como deduções das emissões dos países do Anexo Um. Não houve acordo sobre a magnitude do teto: a União Européia, ao contrário do grupo Guarda-chuva, só aceitaria os sumidouros com teto bastante reduzido.

Em janeiro de 2001, foi aprovado em Shangai o terceiro relatório oficial do IPCC, que alertava contra os riscos da mudança climática e para a necessidade de agir rapidamente. Esse relatório causou grande impacto sobre o Fórum Econômico que ocorreu em Davos uma semana depois.
Neste fórum, o establishment da globalização apelou Bush para que, diante da nova certeza científica sobre a mudança climática, assumisse uma posição de liderança na negociação final de ratificação do Protocolo de Kyoto. No core do governo Bush, o secretário do Tesouro, O'Neill, e o secretário de Estado, Powel, assumiram uma posição favorável, porém moderada, enquanto o vicepresidente, Cheney, a assessora de Segurança Nacional, Rice, e o secretário de Energia, Abraham, foram definitivamente contrários à ratificação do protocolo.

Em março de 2001, o governo Bush anunciou oficialmente que se retirava das negociações do Protocolo de Kyoto por considerá-lo inapropriado para lidar com a mudança climática por duas razões: a falta de relevância depositada aos mecanismos de mercado e o não estabelecimento de compromissos para os países de renda média com rápido crescimento de emissões. A saída dos Estados Unidos causou furor na comunidade internacional, mas, depois de algumas semanas de desorientação, a União Européia decidiu levar adiante as negociações para completar e ratificar o Protocolo.

Em julho de 2001, em Bonn, todos os países, com exceção dos Estados Unidos, chegaram a um acordo sobre a maioria dos pontos que estavam pendentes desde a Conferência de Haia, em 2000. Para obter o apoio dos outros países do grupo Guarda-chuva a União Européia teve de ceder em vários pontos: reconhecer os créditos por seqüestro de carbono através do manejo das florestas e do solo; não colocar restrições ao uso dos mecanismos flexibilizadores; e aceitar um regime reduzido de sanções. Nessas três esferas, o acordo obtido ficou muito aquém daquele proposto pelo governo Clinton em Haia (2000) e que tinha sido rejeitado pela União Européia. Em outra frente, para conseguir o apoio ativo de países não pertencentes ao Anexo Um, a União Européia mobilizou o Canadá, a Noruega, a Suíça, a Nova Zelândia e a Islândia no sentido de prometer financiamentos adicionais (em torno de meio bilhão de dólares por ano) para o desenvolvimento de capacidades institucionais e de transferência de tecnologias limpas, a partir de 2005. 
Depois da saída dos Estados Unidos, a posição negociadora da União Européia baseou-se no princípio de que um acordo mínimo seria melhor do que o encerramento do Protocolo de Kyoto. A arrogância de Bush transformou o Protocolo numa espécie carro-chefe da política exterior da União Européia - passou a ser operado pelos chefes de governo e pelos ministros das relações exteriores, em vez de ficar restrito aos ministérios do meio ambiente. E, no geral, os países passaram a considerar a aprovação de Kyoto um emblema em favor de uma ordem mundial baseada na negociação multilateral, em desacordo com a política unilateralista do governo Bush.

\section{Políticas públicas e sua relação com as emissões de carbono no Brasil e a parti- cipação do país nas negociações do regi- me de mudança climática}

A posição brasileira no sistema internacional sofreu mudanças consideráveis entre 1972 e 1990. Na Conferência de Estocolmo (1972), o Brasil liderou juntamente com a China a aliança dos países periféricos contrários a reconhecer a importância em se discutir os problemas ambientais. O modelo de desenvolvimento, que atingira o ápice em 1972, baseava-se em uma forte depleção dos recursos naturais - considerados, na época, infinitos -, em sistemas industriais muito poluentes e na intensa exploração de mão-de-obra barata e desqualificada. Entre 1950 e 1979, o Brasil era visto pelo sistema mundial como um país que ascendia ao centro. Durante a década de 1970, foi um dos principais receptores de indústrias poluentes advindas dos países desenvolvidos, devido ao "avanço" da consciência ambiental. Com o novo paradigma tecnológico (informação intensiva) que se foi implantando no mundo a partir de início da década de 1980, o Brasil passou a ter características pouco vantajosas para a perspectiva internacional de mercado: os recursos naturais clássicos perderam valor relativo, a tolerância para a poluição tornou-se um estigma e a força de trabalho desqualificada era incapaz de operar os novos sistemas produtivos. Estas são algumas causas fun- damentais da crise e do conseqüente declínio brasileiro na década de 1980, além de variáveis de natureza estritamente política, vinculadas ao caráter da transição democrática e à falta de renovação das elites políticas. Apesar de seu extraordinário custo social, a crise do modelo de desenvolvimento da década de 1980 teve um aspecto benéfico, qual seja, a tomada de consciência da opinião pública dos problemas relacionados à devastação ambiental. Esta extraordinária mudança manifestou-se na posição do governo brasileiro em 1992, muito diversa da posição assumida em Estocolmo, vinte anos antes, e bastante sensível aos problemas ambientais.

Quando Collor nomeou Lutzenberger como secretário de meio ambiente, em março de 1990, estava sinalizando uma nova responsabilidade ambiental que o governo brasileiro pretendia assumir. A súbita conversão ambientalista de Collor explica-se pela necessidade de ganhar a confiança da opinião pública dos países desenvolvidos para seu programa econômico neoliberal, que necessitava novos investimentos estrangeiros. Além disso, Collor também percebeu que a escolha do Brasil para sediar a UNCED-92 por parte da Assembléia Geral da ONU, efetuada poucos dias antes de sua eleição, lhe dava oportunidade para projetar a si próprio e a seu governo no cenário internacional (Viola, 1997).

No primeiro ano de governo, Collor e Lutzenberger tomaram algumas decisões importantes que lhes deram credibilidade na esfera do ambientalismo internacional, quais sejam, prorrogação da suspensão de subsídios e incentivos fiscais para agropecuária na Amazônia, suspensão do programa de ferro-gusa da Amazônia oriental, maior monitoramento e fiscalização do desmatamento com queda de 50\% nas queimadas em agosto/outubro de 1990 (comparadas com o pico de 1988), elaboração do macrozoneamento ecológico-econômico, fim do programa nuclear paralelo dos militares e adesão do Brasil à política ocidental de não-proliferação nuclear. Em conseqüência, Collor tornou-se um presidente confiável para o establishment ocidental.

As reuniões de presidentes em torno do Pacto Amazônico e do Mercosul no início de 1992, 
promovidas pelo Brasil, enfatizaram a necessidade de uma reforma da ordem mundial na direção do desenvolvimento sustentável e do reconhecimento de que também os países emergentes deveriam fazer um esforço significativo para lidar com os problemas ambientais globais.

A posição do governo brasileiro no processo preparatório e na realização da Rio-92 baseou-se em dois princípios. Em primeiro lugar, de que os problemas ambientais globais eram relevantes e deveriam ser tratados de maneira prioritária pela comunidade internacional; em segundo, de que a responsabilidade se diferenciava tanto pela causa quanto pela solução dos problemas ambientais globais, o que aumentava o custo dos países ricos. Contudo, a operacionalização da posição brasileira nos PREPCOMS (até março de 1992) foi afetada pelas divergências entre o Itamaraty e Lutzenberger, que mantinha uma posição mais radical. Um pouco antes e durante a conferência (maio/junho de 1992), o governo brasileiro passou a implementar uma política exterior mais responsável quanto aos problemas ambientais globais, mudança iniciada em 1989: assumiu um papel de co-liderança durante a redação dos resultados da Convenção de Biodiversidade, facilitou o acordo na convenção de mudança climática e teve posições consistentes e favoráveis a compromissos em favor do desenvolvimento sustentável na Agenda 21 (Guimarães, 1994; Lafer e Fonseca, 1994). Entretanto, a posição brasileira ficou aprisionada pelo velho nacionalismo ao apoiar a Malásia na oposição a uma convenção sobre florestas.

Na UNCED, o Brasil assumiu uma posição que pode ser considerada globalista ou neosocialdemocrata, mesmo que inserida numa estrutura estatal em que ainda predomina o nacionalismo. A posição neosocialdemocrata foi influenciada por cinco fatores: 1) crise do modelo desenvolvimentista brasileiro na década de 1980 que produziu uma significativa abertura da opinião pública para com a idéia de desenvolvimento sustentável, mesmo que de forma difusa; 2) sensibilização do governo em relação aos problemas ambientais, já que o país detinha a soberania de $2 / 3$ da maior floresta pluvial do mundo e havia, portanto, a necessidade de considerar o impacto ambiental; 3) o fato de a matriz energética brasileira estar fundada em recursos naturais renováveis (basicamente hidroelétrica e biomassa) num contexto em que a quase totalidade dos países é dependente de combustíveis fósseis ou de energia nuclear; 4) a consciência da importância da floresta Amazônica - grande reservatório mundial de biodiversidade e de apreensão de carbono - que tornava, conseqüentemente, a política favorável ao desmatamento (predominante até 1988) um consenso favorável a uma combinação de preservação com desenvolvimento sustentável; 5) pressão pelo compromisso com o globalismo, já que o Brasil era o país-sede da UNCED-92.

O governo Cardoso sedimentou a mudança na política externa iniciada por Collor. Houve um reforço dos laços econômicos com os Estados Unidos, a União Européia e o Japão e abandonaram-se as tentativas prévias de estabelecer relações privilegiadas com a China, a Rússia e a Índia. O Brasil aliou-se com os Estados Unidos e a Europa na maioria dos foros multilaterais: proteção dos direitos humanos, dos direitos da mulher e dos direitos reprodutivos; proteção do direito de propriedade intelectual; expansão do papel do Fundo Monetário Internacional, do Banco Mundial e da Organização Mundial de Comércio; esforços internacionais para combater o terrorismo e o crime globalizado. Fernando Henrique Cardoso assinou, com muitos anos de atraso, os tratados de não proliferação nuclear e de controle de tecnologia de mísseis. De uma maneira geral, seu governo tem um perfil neosocialdemocrata no que diz respeito à inserção internacional do país, mas, em aspectos secundários, o Itamaraty mantém abordagens nacionalistas, como a continuidade de filiação ao Bloco G77 (com o intuito de ter apoio para o país se tornar um novo membro permanente do Conselho de Segurança da ONU), a tentativa de atrasar a formação da Associação de Livre Comércio Americana (ALCA), a crítica à Argentina, devido à nova aliança militar deste país com os Estados Unidos e a oposição à intervenção da OTAN em Kosovo.

A política energética deste governo seguiu os seguintes eixos: privatização da geração e da distribuição de eletricidade; manutenção da pro- 
priedade estatal da transmissão de eletricidade; novo modelo regulatório favorável a incrementar a geração termoeléctrica, baseada em gás natural, e a co-geração; quebra do monopólio da Petrobrás na produção de petróleo e abertura de novos campos petrolíferos pelo setor privado. A privatização da distribuição de energia elétrica realizouse segundo o que fora programado, mas a privatização da geração sofreu atrasos e resistências por parte de sindicatos e políticos nacionalistas. Os preços da energia elétrica continuaram relativamente baixos (fator importante para reduzir a inflação anual em um ou dois pontos percentuais, entre 1995 e 2000), o que desestimulou o investimento em geração. A construção de novas termoeléctricas a gás natural atrasou devido à paralisia decisória relativa ao modelo regulatório (risco cambial do gás natural importado). Como conseqüência dos preços relativamente baixos da energia, da limitada privatização das geradoras e do atraso na definição do risco cambial do gás, os investimentos em geração de eletricidade num contexto de expansão significativa da demanda foram bastante limitados. A não privatização de grandes geradoras, como Furnas e CHSF, dissuadiu novos investimentos de porte por parte de corporações transnacionais, pois a promiscuidade potencial entre o Estado e as empresas estatais criaria uma desvantagem competitiva. Na região Sul, onde a geradora Eletrosul foi comprada por uma empresa belga, houve novos investimentos privados importantes em geração. O estrangulamento da oferta, os níveis de precipitação inferiores aos normais nos últimos cinco anos e os erros na condução do sistema, que reduziram perigosamente o nível dos reservatórios, provocaram uma crise no abastecimento de energia elétrica a partir de maio de 2001. O racionamento implementado entre junho de 2001 e fevereiro de 2002 (redução de 20\% do consumo) causou duplo impacto: de um lado, havia tanto espaço para aumentar a eficiência energética do conjunto da economia, quanto uma boa disposição da população para colaborar com o racionamento; de outro, alguns setores econômicos tiveram de reduzir parcialmente seu nível de atividade, provocando uma brusca parada na curva de crescimento econômico que se desenvolvia desde o final de 1999.

Em 2001, o Brasil gerou mais de 90\% de sua eletricidade a partir de fontes hídricas e continua ocupando um lugar de destaque na hidroeletricidade mundial (apenas atrás da Noruega e da Áustria). A expansão do consumo de petróleo e derivados durante a década de 1990 foi significativa devido à expansão do parque de automóveis e a diminuição drástica da produção de carros movidos a etanol. O plano de expansão de ferrovias e hidrovias para o período de 2000-2010 fará com que o aumento do consumo de derivados do petróleo no setor de cargas nos próximos anos venha a ser inferior ao da década de 1990. Por outro lado, a grande expansão das termoeléctricas na geração de eletricidade deverá aumentar as emissões de carbono derivadas do setor energético.

A política externa do governo Cardoso no que se referente a questões ambientais tem tido posições bastante diferenciadas nos foros internacionais. Na Comissão de Desenvolvimento Sustentável da ONU, o Brasil sugeriu propostas neosocialdemocratas e, em contrapartida, no debate sobre o estabelecimento de padrões mínimos de proteção ambiental no comércio internacional, assumiu posições nitidamente neoliberais. No Mercosul, o país não conseguiu se tornar uma liderança capaz de introduzir de modo mais contundente a sustentabilidade ambiental na agenda da integração. O Protocolo Ambiental do Mercosul, negociado em 1996/1999, constituiu-se um avanço importante, embora sua assinatura tenha sido bloqueada no último momento por certa ambivalência dos setores mais conservadores do empresariado argentino.

O núcleo do governo tem concebido a Amazônia como uma área destinada basicamente a ser ocupada por atividades econômicas de modo não seletivo, desde que não se promovam desmatamentos excessivos que coloque em risco a estabilidade do clima regional e de que haja o mínimo de responsabilidade nesta ocupação, como exige a comunidade internacional. A correlação de forças políticas a respeito da Amazônia se dá por uma coalizão entre neoliberais e nacionalistas. O crescimento da demanda por madeira, a existência de 
vastos contingentes populacionais em condições de pobreza, e, em razão disso, uma tendência ao comportamento predatório, a extrema falta de habilidade na condução das políticas de instituições como o Ibama e agências ambientais estaduais e, por fim, a visão de desenvolvimento encerrada numa perspectiva de curto prazo por parte das elites locais têm sido as causas fundamentais do desmatamento na Amazônia. Em 1988, a superfície desmatada foi de aproximadamente $28.000 \mathrm{Km}^{2}$, equivalente a $0,82 \%$ da área total da Amazônia. No período de 1989 a 1994, houve uma queda substancial, correspondente a uma média de aproximadamente 0,40\% ao ano. Em 1995, o desmatamento teve um novo pico, com $27.000 \mathrm{Km}^{2}(0,77 \%$ da área total), devido, em grande medida, ao crescimento econômico relativo à primeira fase do plano Real. Em 1996 e 1997, verifica-se uma nova queda, com uma média anual de 0,40\%. A partir de 1998, ocorreu um novo crescimento - 0,47\%, em 1998, 0,48\%, em 1999 e 0,62\%, em 2000. Assim, observa-se que há uma relação imediata entre o crescimento da economia nacional e o crescimento do desmatamento na Amazônia.

Quanto às emissões de carbono, o país que se pretende globalizado e moderno tem sido refém daquilo que, em contraposição, podemos chamar de tradicional e marginalizado. Em 2000, a população brasileira era aproximadamente 2,8\% da população mundial, com uma economia aproximadamente 2,9\% da economia mundial (PIB calculado por poder de compra), e as emissões de carbono alcançava a taxa em torno de 2,5\% das emissões mundiais (25\% advindo da indústria e da agricultura moderna e 75\% da agricultura tradicional, da conversão de uso na fronteira agrícola e das atividades madeireiras ineficientes e predatórias). Cerca de $80 \%$ da população está vinculada a atividades produtivas que não dependem de altas emissões de carbono e, conseqüentemente, o Brasil possui uma taxa de emissão per capita e por unidade de PIB bem inferior à média mundial. Isto é, sobretudo, decorrência do alto peso da hidroeletricidade na matriz energética. Ademais, aproximadamente $20 \%$ da população está ligada direta ou indiretamente à agricultura tradicional, à conversão de uso da terra na fronteira agrícola e à atividade madeireira ineficiente e predatória, o que indica uma responsabilidade por emissões de carbono per capita e por unidade de PIB muito superiores à média mundial. Estas atividades econômicas representam menos de 10\% do PIB brasileiro.

O Estado tem sido irresponsável em relação ao controle do crime organizado na Amazônia, e isto se constitui, neste início de século, o principal problema para a consistência e a eficiência das políticas públicas na Amazônia. A postura do governo federal favoreceu certa conivência com o narcotráfico nos governos estaduais e municipais da Amazônia, com exceção do Acre (1999-2002), que implementou uma política no sentido contrário (Viola, 1999). A intensificação da guerra civil na Colômbia a partir de 1997 é um dos fatores que mais promoveram o crescimento do narcotráfico na região amazônica. Esta situação agravou-se com a utilização em grande escala de desfoliantes biológicos contra as plantações de coca, a partir de 2001, por parte do Estado colombiano com o apoio dos Estados Unidos. O uso prolongado desse produto poderá ter conseqüências mais graves, afetando a integridade ecológica de uma parte da floresta. O aumento exponencial do consumo de drogas ilegais no país também estimula o narcotráfico na Amazônia e em outras regiões do país, o que confere ao Brasil um lugar de destaque no ciclo global da cocaína (plantação de coca, refino, distribuição local/mundial e consumo). Apenas o plantio da coca ainda está ausente do território brasileiro.

A contraposição, já aludida, entre dois brasis, um globalizado e moderno e outro tradicional e marginalizado é um dos grandes paradoxos de nossa época. Tal paradoxo pode ser explicado, do ponto de vista econômico e ecológico, pelo fato de a economia brasileira ter sido, durante mais de quatro séculos, pautada pelo desmatamento, e, agora, passar a reprimir queimadas significa não só romper com uma tradição, mas também golpear interesses econômico-sociais, mesmo que de pouca importância no presente. O custo econômico da redução da agricultura de queimada, da conversão irracional de uso na fronteira agrícola e das atividades madeireiras ineficientes seria relativamente pequeno. Para isso seria necessário: 
1. Políticas sociais que melhorem o nível educacional e acelerem a distribuição de terras e de tecnologia complementar entre a população que hoje depende da agricultura tradicional e da conversão do uso da terra.

2. Políticas de controle sobre as atividades madeireiras ineficientes e predatórias acompanhadas de estímulo para convertê-las em atividades eficientes e relativamente sustentáveis.

3. Atuação coordenada do Poder Judiciário, do Ministério Público, da Polícia Federal e das Forças Armadas para fortalecer o Estado de Direito na Amazônia.

A atuação do Brasil durante a negociação do Protocolo de Kyoto (1996-2001) orientou-se pela definição do interesse nacional segundo quatro dimensões principais: 1) afirmar o direito ao desenvolvimento como um componente fundamental da ordem mundial, dando continuidade à política externa brasileira; 2) promover uma visão do desenvolvimento associada com a sustentabilidade ambiental, em correspondência com o grande crescimento da consciência ambiental no país e sua tradução em políticas públicas nacionais e estaduais; 3) promover uma posição de liderança do Brasil no mundo, em correspondência com o crescimento do prestígio internacional do país durante o governo Cardoso; e 4) evitar que o uso das florestas seja objeto de regulação internacional para não correr riscos de que outros países possam questionar o uso econômico da Amazônia. É importante salientar que a entrada das florestas no regime mundial de clima não foi percebida como uma ameaça à soberania nacional por outros países: Estados Unidos, Canadá, Rússia, Austrália e Costa Rica, entre outros, promoveram com intensidade a regulação internacional das florestas. As características específicas do posicionamento brasileiro nas diversas questões do Protocolo de Kyoto são assinaladas a seguir.

A delegação brasileira esteve sempre sob o comando do Ministério da Ciência e Tecnologia (o presidente da Agência Espacial Brasileira, Meira Filho, teve um papel fundamental) nos aspectos substantivos e do Itamaraty nos aspectos relacio- nados ao processo negociador. Até 1999, a presidência da República não considerou a negociação do Protocolo uma questão importante sobre a qual deveria interferir. A definição do posicionamento brasileiro ficou muito restrita entre 1996 e 1999, quase sem a participação de governos estaduais, empresários ou ONGs. A partir de 2000, a arena de definição ampliou-se com a inclusão, em posição secundária, do Ministério do Meio Ambiente, do Conselho Empresarial Brasileiro para o Desenvolvimento Sustentável, de alguns governos estaduais da Amazônia e de várias ONGs. Em junho de 2000, por iniciativa da presidência da República e do ex-deputado federal Fabio Feldmann, foi criado o Fórum Brasileiro de Mudanças Climáticas, de caráter multissetorial, que reuniu diversos atores governamentais, empresariais, não governamentais e acadêmicos. Este fórum constituir-se-á uma inovação tanto em termos de criar uma arena propícia para a formação do posicionamento nacional quanto de internalizar o regime de clima dentro do país. A partir de outubro de 2000, o Ministério do Meio Ambiente e governos de alguns Estados amazônicos questionaram a tradição brasileira de ter um posição contrária à inclusão do ciclo do carbono no Protocolo (sumidouros por meio de florestas e do manejo do solo). Muitas ONGs, particularmente aquelas que têm grande atuação na Amazônia, pressionaram o governo para apoiar a inclusão de projetos relacionados à proteção de florestas primárias no Mecanismo de Desenvolvimento Limpo. Contudo, a posição do Ministério de Ciência e Tecnologia e do Itamaraty continuou predominando.

No Grupo G77/China, o Brasil sempre teve uma posição de liderança, e tornou-se uma ponte para o diálogo entre países desenvolvidos e aqueles que mais se confrontavam com estes, como Índia, China, Indonésia e Malásia. A comissão brasileira manteve a opinião de que toda a responsabilidade pela redução das emissões era dos países desenvolvidos e, portanto, opôs-se deliberadamente aos compromissos de redução da taxa de crescimento futuro das emissões por parte dos países emergentes. Isto lhe causou vários momentos de confronto, particularmente com os Estados Unidos, em várias ocasiões, e com a Argentina, 
em 1998/1999. O princípio que norteia as propostas do país é de que as emissões de carbono deveriam ser calculadas diacronicamente, ou seja, a partir acumulação de emissão ocorrida desde o final do século XVIII e não apenas a partir do ano base de 1990. Embora esta posição tenha contado com forte apoio da maioria dos países não pertencentes ao Anexo Um, não é levada a sério pelos governos dos países pertencentes ao Anexo Um e, assim, não tem tido, no processo negociador, o impacto esperado, pelo menos até o final de 2001. A proposta brasileira é consistente em termos técnicos, legítima do ponto de vista histórico e eqüitativa no sentido de apresentar uma abordagem teórica baseada em direitos universais da população mundial ao uso da atmosfera como um bem público global, mas pode ser considerada, atualmente, utópica por estar distante da realidade efetiva do poder mundial. Apesar disso, é bem provável que esta proposta acabe contribuindo para melhorar a capacidade argumentativa dos países emergentes na negociação geral sobre a questão dos seus compromissos de redução.

Em junho de 1997, o Brasil, como já foi dito, fez uma proposta original, o Fundo de Desenvolvimento Limpo (FDL), que teve grande apoio dos países emergentes e pobres, mas, como era de se esperar, foi extremamente criticada por todos os países desenvolvidos. Contudo, em outubro de 1997, aconteceu um desdobramento inesperado: os Estados Unidos e o Brasil articularam uma versão alterada do FDL, que passou a se chamar Mecanismo de Desenvolvimento Limpo (MDL), considerado uma das novidades do Protocolo de Kyoto. O MDL abriu a possibilidade de os países desenvolvidos cumprirem parte de suas metas de redução de emissão por meio do financiamento de projetos de desenvolvimento sustentável nos países emergentes e pobres. Por causa dele o Brasil aceitou a proposta de mecanismos flexibilizadores de mercado para complementar os compromissos de redução de emissões dos países desenvolvidos, e isto significou a ruptura do país em relação à sua posição, marcada pela oposição à implementação conjunta (prevista na Convenção do Rio de Janeiro) e às cotas comercializáveis de emissão entre os países do Anexo Um.
O acordo em torno do MDL foi um momento notável de colaboração entre a diplomacia norte-americana e a brasileira, pois a negociação implicou uma vitória para todos os países. O componente mais flexível e criativo da posição brasileira em todas as negociações do Protocolo revelou-se na sua capacidade de articulação política, sobretudo com a diplomacia norte-americana, em outubro de 1997, quando da elaboração deste mecanismo inovador. Entre 1999 e 2001, o país liderou uma proposta vitoriosa para que o MDL fosse o primeiro dos três mecanismos flexibilizadores a ser implementado e para que, no seu conselho diretor, os países emergentes e pobres tivessem uma representação mais forte do que a obtida no Global Environment Facility.

Com relação aos sumidouros de carbono, o interesse nacional foi o de assumir uma posição defensiva: a floresta amazônica tornou-se mais um ônus por causa do desmatamento do que um trunfo em virtude do serviço global de seqüestro de carbono. O que estava implícito nas declarações dos negociadores brasileiros era que o país não conseguiria conter de maneira significativa $\mathrm{O}$ desmatamento na Amazônia. Isso levou o Brasil a se posicionar contra a inclusão do conjunto de propostas em torno do ciclo do carbono, temendo que, no futuro, quando se estabelecerem compromissos para os países emergentes, o Brasil possa vir a ter um grande passivo advindo do desmatamento na Amazônia. Como resultado final do Protocolo a respeito dessas questões, o Brasil e a União Européia, por um lado, foram derrotados os sumidouros de carbono passaram a fazer parte do Protocolo -, e, por outro, saíram vitoriosos apenas o reflorestamento e o florestamento poderão ser considerados atividades de seqüestro de carbono, ficando de fora do MDL atividades orientadas a evitar o desmatamento de florestas primárias. Nesta questão específica, o Brasil ficou em minoria entre os países não pertencentes ao Anexo Um, particularmente na América Latina.

Apesar de ser um país em desenvolvimento com matriz energética limpa, o Brasil assumiu uma aliança geral com países emergentes com matriz energética dependente de combustíveis fósseis (China, Índia e Indonésia). A vantagem da matriz 
energética ficou sempre subordinada à desvantagem do desmatamento na Amazônia na formação da posição brasileira. Por isso, o país se aliou, em geral, com a União Européia contra os países florestais com capacidade de controle do desmatamento (Estados Unidos, Canadá, Austrália, Rússia, Japão e Costa Rica) na questão da inclusão dos sumidouros de carbono na contabilidade de emissões e, conseqüentemente, na valorização do serviço global prestado pelas florestas como seqüestradores de carbono. Uma visão alternativa e positiva sobre a Amazônia teria levado o Brasil a uma aliança inversa, o que talvez influenciasse sobremaneira o perfil final do Protocolo.

Com uma posição de forte liderança na questão de reafirmar a necessidade de novos fundos financeiros dos países desenvolvidos para o financiamento de transferência de tecnologias limpas e para o desenvolvimento da capacidade institucional nos países emergentes, o Brasil sobressaiu, obtendo vitórias parciais a este respeito na Conferência de Bonn (2001). A ênfase na transferência facilitada de tecnologias produtivas limpas é coerente com o objetivo geral da política externa brasileira do governo Cardoso, no sentido de promover a inserção competitiva do país na economia globalizada.

Reiterando, as relações entre Brasil e Estados Unidos no âmbito do Protocolo tornaram-se difíceis desde meados de 1999. Os Estados Unidos são favoráveis a compromissos de redução da taxa de crescimento futuro das emissões para os países emergentes no primeiro período (2010), enquanto o Brasil mantém sua posição contrária; o Brasil opõe-se à inclusão das florestas nativas no MDL, ao contrário dos Estados Unidos que, por sua vez, propõem um regime reduzido de sanções, entrando em confronto com a posição da União Européia, apoiada pelo Brasil. Finalmente, o Brasil, somando força com a União Européia, tentou impor limites aos sumidouros de carbono para os países desenvolvidos, o que foi também motivo de conflito e disputa com os Estados Unidos durante as negociações. Desde a saída dos Estados Unidos do Protocolo (março de 2001) até a conclusão das negociações (novembro de 2001), o Brasil destacouse tanto na crítica da posição norte-americana como na promoção das negociações entre os diversos blocos. Além disso, foi liderança na articulação da aliança entre a União Européia e os países emergentes, o que possibilitou o sucesso da negociação final do Protocolo. Em vários discursos internacionais - antes e depois do 11 de setembro - o presidente Fernando Henrique criticou incisiva e consistentemente a política unilateral do governo Bush em relação ao regime de mudança climática. Ao se comparar as posições dos dois países entre 1989 e 2001, observa-se claramente uma inversão de papéis: em 1989, o governo Bush (pai), aliado aos outros países desenvolvidos, criticava o governo Sarney pela contribuição do país para a mudança climática em virtude do intenso desmatamento na Amazônia; em 2001, o governo Cardoso, aliado aos países desenvolvidos, criticava o governo Bush pela falta de uma atitude responsável em relação ao clima global.

Desde 2000, o presidente Fernando Henrique tem elevado o nível da participação brasileira no Protocolo de Kyoto, e isto promete bons frutos para o país. A viabilidade de longo prazo do Protocolo de Kyoto depende do retorno dos Estados Unidos ao regime e da aceitação de compromissos de redução da taxa de crescimento futuro das emissões por parte dos países emergentes (as emissões poderão continuar a crescer, mas a um ritmo menor). A posição do Brasil será provavelmente decisiva a este respeito, já que, entre os países emergentes, é o melhor situado para avançar no processo de negociação. Entretanto, é essencial que consiga diminuir o ritmo do desmatamento na Amazônia, o que contaria com o apoio da maioria da população. Com certeza, uma coalizão para o uso mais racional da floresta amazônica teria impactos favoráveis não apenas internamente, mas também no âmbito internacional, elevando o prestígio do país no mundo e ganhando, com isso, a cooperação internacional em geral.

\section{Perspectivas do protocolo de Kyoto depois dos acordos de Bonn e Marrakesh}

Apesar do clima pessimista desde março de 2001 causado pelo posicionamento de Bush, a 
maioria das questões principais pendentes do Protocolo foram negociadas com sucesso na Conferência das Partes em Bonn (julho de 2001 - continuação da COP6, suspensa em Haia, em novembro de 2000). Para a realização do Acordo, todas as partes contribuíram. A União Européia fez mais concessões do que em Haia; os países do G77 moderaram suas demandas, os países do grupo Guarda-chuva abandonaram os Estados Unidos; as ONGs internacionais (principalmente World Wide Fund for Nature, Friends of the Earth e GreenPeace) diminuíram suas exigências em prol de um acordo; os Estados Unidos aceitaram a derrota e não bloquearam as negociações; e o holandês Pronk, presidente da conferência, teve uma liderança mais firme e incisiva do que em Haia. Alguns dos pontos específicos, ainda pendentes, foram negociados com sucesso na VII Conferência das Partes, em Marrocos (novembro de 2001): ampliou-se o teto de contabilidade de sumidouros de carbono para Rússia e estabeleceu-se, de um modo genérico, que haveria um regime de sanções para os países do Anexo Um que não cumprissem os compromissos estabelecidos de redução de emissões até 2010. Outros pontos específicos ficaram para ser negociados na Primeira Conferência das Partes depois da ratificação do Protocolo: o regime específico de sanções, o qual será agregado posteriormente como uma emenda ao Protocolo de Kyoto, e as bases para aprovação de projetos inseridos no Mecanismo de Desenvolvimento Limpo e na Implementação Conjunta. Os países, liderados pela União Européia, estabeleceram como meta a ratificação do Protocolo para a Conferência das Nações Unidas sobre Desenvolvimento Sustentável a ser realizada em Joanesburgo, em setembro de 2002.

Ao que tudo indica, o Protocolo está em via de ser ratificado para entrar em vigência em 2003. Isso requer a ratificação de pelo menos cinqüenta países, dos quais aqueles pertencentes ao Anexo Um devem responder por no mínimo 55\% das emissões deste grupo, segundo o ano base de 1990. Como nesta data os Estados Unidos foi responsável por 35\% das emissões dos países do Anexo Um, o protocolo precisa ser obrigatoriamente ratificado pela União Européia, Rússia e Ja- pão mais dois países (Canadá, Austrália, Ucrânia ou Polônia). Até julho de 2002, a União Européia e o Japão já tinham ratificado o Protocolo e havia uma boa perspectiva de ratificação por parte da Rússia, da Ucrânia e da Polônia até o final de 2002. O Canadá e a Austrália talvez não ratifiquem-no. O Congresso brasileiro o validou em junho de 2002.

Resta saber se o Protocolo será um instrumento efetivo na luta para atenuar a mudança climática ou se representará apenas os anseios universalistas da humanidade em contraposição à resistência da política unilateralista norte-americana. De fato, a situação é complexa, pois o próprio contexto em que se deram as negociações do Protocolo é repleto de contradição. É necessário a consideração de diversas dimensões para se poder avaliar com mais densidade o significado do atual Protocolo de Kyoto: sustentabilidade de longo prazo em virtude da saída dos Estados Unidos, principal país emissor de carbono na atmosfera, e da pressão da opinião pública internacional, perda potencial de competitividade das empresas européias e japonesas, que terão mais custos ao mudar o processo produtivo rumo a uma diminuição da emissão de carbono, capacidade de impulsar as medidas por parte de empresas que estão assumindo compromissos voluntários, consolidação institucional do mercado de carbono, força relativa do setor conservador na sociedade norte-americana, emergência de uma proposta alternativa a Kyoto por parte do governo Bush num futuro próximo e força relativa dos setores que impulsionam compromissos de redução da taxa de crescimento futura das emissões nos países em desenvolvimento.

Pela primeira vez na história contemporânea um tema desvinculado diretamente de questões clássicas, como segurança ou economia, ocupou o lugar principal na agenda dos países. Assim como, pela primeira vez depois da Segunda Guerra Mundial, os Estados Unidos e a Europa ocidental entraram em confronto em torno de uma questão de alta relevância na arena internacional. A política unilateralista de Bush está em desacordo com a linha adotada pelos Estados Unidos desde o final da Guerra Fria. Em dezoito meses de admi- 
nistração Bush, o país assumiu posições unilaterais em pelo menos outras seis questões internacionais importantes: 1) decisão de construir o Escudo de Defesa Antimíssil - e, conseqüentemente, quebrar o compromisso do Tratado contra os Mísseis Antibalísticos de 1972); 2) decisão de se retirar da negociação do Protocolo de Verificação do Tratado contra as Armas Biológicas; 3) oposição a uma convenção eficiente sobre o uso de pequenas armas; 4- saída da Conferência sobre Racismo, em Durban; 4) definição do "Eixo do Mal" (Iraque, Irã e Coréia do Norte), incentivando a mudança de regime político nesses países; e 6) envolvimento precário na negociação de um acordo efetivo de paz e de criação do Estado palestino, condicionando sua maior participação à substituição de Arafat na liderança palestina. Apesar de já ter havido outras ocasiões em que os Estados Unidos ficaram isolados politicamente nas últimas décadas - Lei do Mar, de 1983, Tratado de Banimento das Minas Terrestres, de 1997, e o tratado que criou o Tribunal Penal Internacional, de 1998) -, nunca isto tinha acontecido em torno de uma questão de "alta política", como o Protocolo de Kyoto. Além disso, há uma forte oposição interna e externa que está implicando custos importantes em termos do prestígio do país no âmbito internacional.

Responsável por um quarto das emissões globais de carbono, os Estados Unidos são, obviamente, imprescindíveis na mesa de negociação. Sem ratificar o Tratado, poderá haver um crescimento das emissões de carbono dos Estados Unidos, ao contrário dos outros países do Anexo Um. Assim, por exemplo, em 2010 as emissões da União Européia deverão ser 8\% inferiores as de 1990 e as dos Estados Unidos (caso permaneça a tendência atual) serão cerca de 30\% superiores as de 1990, o que, com certeza, trará dificuldade para a sobrevivência dos acordos estabelecidos no Protocolo, visto que as condições de competitividade no mercado global se tornariam injustas, como já foi dito. Em contrapartida, a energia eólica já se tornou comercialmente competitiva em todo o mundo, e uma boa parte da descarbonização poderá se dar com o crescimento da proporção das turbinas eólicas na geração energética mundial. Na Dinamarca, por exemplo, 26\% da energia elétrica já é produzida por turbinas eólicas, na Alemanha e na Holanda, 4\%, e na Espanha, 3\%. Na maioria dos países europeus a energia eólica cresce a taxas muito altas desde 1998.

A assinatura do Protocolo de Kyoto, em 1997, desencadeou um movimento em setores do empresariado dos países desenvolvidos em favor de novas tecnologias não-carbonizantes, tanto na área energética como no conjunto do ciclo produtivo. Desde 1999, metas voluntárias de redução de carbono vêm sendo assumidas por grandes empresas comprometidas com o regime de mudança climática e impulsionadas, é claro, pela criação, em Bonn, de um arcabouço internacional obrigatório (BP, Shell, Volvo, Dupont, Cisco, Conoco, Toyota e Honda). Segundo essas empresas, os Estados Unidos serão praticamente obrigados a aderir ao Protocolo de Kyoto em poucos anos, até mesmo porque o modelo constituído na conferência de Bonn está muito próximo das posições defendidas pelos negociadores norte-americanos desde 1996, quais sejam, atenção diferencial aos mecanismos flexibilizadores de mercado (comércio e certificação ilimitada de cotas de emissão de carbono entre os países do Anexo Um e garantia de créditos na balança da redução de emissões quando do desenvolvimento de projetos realizados em países não pertencentes ao Anexo Um), consideração do conjunto do ciclo do carbono incluindo sumidouros e regime de sanções restrito.

O incipiente mercado de carbono já produziu cerca de sessenta transações que envolveram aproximadamente 100 milhões de dólares. Soma apenas simbólica, visto que as estimativas sobre as transações de carbono anuais por volta de 2005 deverão oscilar entre 5 a 10 bilhões de dólares por ano, sem a presença dos Estados Unidos, e entre 40 a 100 bilhões com sua presença. Ademais, o valor unitário da tonelada de carbono cairá significativamente sem os Estados Unidos, assim como o comércio de carbono tornará menor o custo advindo do cumprimento das metas de redução (por parte dos países do Anexo Um com mais dificuldades para cortar emissões internamente) e criará novas oportunidades de negócio para empresas mais dinâmicas, incentivando energias renováveis, 
incrementando a eficiência energética dos equipamentos e melhorando o manejo das florestas e dos solos). Países como Reino Unido, Dinamarca e Noruega lançarão seus mercados internos de carbono nos próximos meses, e apesar da não ratificação do Protocolo, os Estados Unidos assistem ao surgimento da, Chicago Climate Exchange, instituição destinada a promover o mercado de carbono entre as empresas norte-americanas que assumiram compromissos voluntários de redução de emissões. Além disso, o Banco Mundial vem desenvolvendo, com sucesso, um Programa Piloto de Mercado de Carbono desde 1999.

O Brasil é um dos países não pertencentes ao Anexo Um mais ativo no mercado internacional de carbono por meio do MDL, e já existem no país algumas firmas que iniciaram suas operações como brokers. A criação do Fórum Brasileiro de Mudanças Climáticas, de caráter multissetorial (governo, empresas e ONGs), em 2000, tem contribuído muito para a participação do Brasil no incipiente mercado de carbono. Além disso, há um grande potencial para o desenvolvimento da energia eólica por causa de três fatores combinados: existência de grandes bacias de vento em quase todo o litoral, estímulo do MDL e necessidade de aumentar rapidamente a oferta de energia devido à crise dos reservatórios de hidroeletricidade em 2001. Contudo, como mecanismo flexibilizador, o MDL compete em condições desfavoráveis com o comércio de cotas de emissões, particularmente com a nova proposta russa de Esquema de Investimento Verde, que poderá dominar a compra de créditos de emissões por parte dos países mais necessitados, como Japão, Canadá e Austrália.

Mas é preciso se perguntar se o mercado de carbono poderá se desenvolver plenamente sem uma rápida adesão dos Estados Unidos ao Protocolo, ou, ainda, se a existência de mercados de carbono nacionais e regionais garantirá o efetivo mercado global com normas, padrões e compromissos comuns.

A todo movimento favorável ao Protocolo de algum importante setor do empresariado dos países desenvolvidos observa-se um movimento contrário do empresariado conservador norte-americano, que acredita que as sociedades desenvolvi- das (e, em particular, a norte-americana) poderão se adaptar sem maiores problemas à mudança climática e que o custo advindo da redução de emissão seria muito alto comparado ao da adaptação. Esta visão não se preocupa, evidentemente, com as dificuldades enfrentadas pelos países em desenvolvimento e, sobretudo, os de baixa renda. Mesmo que de maneira implícita, mas não por isso menos definida, vem à tona a mentalidade dos conservadores republicanos, ou seja, justificam a falta de solidariedade pela incompetência e, conseqüentemente, o fracasso - dos países pobres em conduzir sua política e sua economia envolvidas no facciosismo, na corrupção e nas epidemias. Os Estados Unidos devem, de acordo com esta perspectiva, se manter bem distantes.

Duas outras incertezas pairam sobre o Protocolo de Kyoto. Em primeiro, os negociadores de Bonn deixaram para um futuro incerto a questão dos compromissos de redução da taxa de crescimento futuro por parte dos países de renda média. Em segundo, o governo Bush poderia propor, num futuro próximo, uma alternativa a Kyoto, que enfatizasse menos o controle de emissões no curto prazo e incentivasse a longo prazo o desenvolvimento de tecnologias limpas e a transferência de tecnologia para os países em desenvolvimento. Uma proposta desse tipo poderia obter amplo apoio tanto entre os países desenvolvidos membros do grupo Guarda-chuva como entre os países em desenvolvimento, o que, talvez, fosse mais eficiente do que o Protocolo de Kyoto sem os Estados Unidos. A situação de derrota experimentada pelo país em Bonn seria revertida pela aprovação de um novo mecanismo global liderado então pelos Estados Unidos.

Portanto, o futuro do Protocolo de Kyoto é incerto e dependerá:

- A Da capacidade de as elites européias, juntamente com as elites globalistas responsáveis norte-americanas, persuadirem em seu favor a opinião pública dos Estados Unidos.

- Da capacidade de as elites européias, juntamente com as elites globalistas responsáveis dos países de renda média, persuadirem a população desses países em favor da necessidade 
de compromissos de redução da taxa de crescimento futuro das emissões.

- Do sucesso de os setores empresariais, já comprometidos com as metas estabelecidas, produzirem no curto prazo inovações tecnológicas eficientes.

- Da rapidez com que o setor empresarial de energia eólica desenvolva um ambiente regulatório favorável na maior parte do mundo.

- Do sucesso de governos, empresas e ONGs em desenvolver e consolidar um mercado global de carbono.

- Das dificuldades de o governo Bush elaborar uma proposta alternativa que seja atrativa para a maioria dos países-chave.

Passando para um contexto mais amplo, o futuro do regime de mudança climática e do Protocolo de Kyoto, em particular, dependerá da atitude e do comportamento predominantes, a médio prazo, nos países desenvolvidos no sentido de assumir os custos e as responsabilidades da governabilidade global e da produção de bens públicos globais (como mecanismos para um desenvolvimento econômico mais inclusivo e para enfrentar os problemas epidemiológicos e ambientais), além da reconstrução dos Estados fracassados. Os custos e as responsabilidades estão vinculados à emergência de uma ação do tipo "Plano Marshall", que forneceria uma maior estrutura aos países em dificuldade. Lembremos que o Plano Marshall implicou o destino de cerca de 3\% do PIB norte-americano, durante cinco anos (1948-1952), para a reconstrução da Europa ocidental e do Japão. Dedicar uma proporção equivalente do PIB dos países desenvolvidos durante uma década a esses países causaria um impacto gigantesco sobre a governabilidade do mundo sem impor um ônus significativo às populações. Mas, infelizmente, as diretrizes tomadas na última década caminham em sentido contrário das necessidades de governabilidade global: a proporção do PIB dos países desenvolvidos destinada à ajuda ao desenvolvimento caiu, aproximadamente, de 0,4\% do PIB, em 1990, para $0,2 \%$ do PIB, em 2000.
A questão que se coloca então é: qual foi o impacto do atentado de 11 de setembro nos Estados Unidos sobre a população dos países desenvolvidos com relação à sua disponibilidade para assumir os custos e as responsabilidades da governabilidade global? A ameaça do comunismo fez com que, no início da Guerra Fria, os Estados Unidos pagassem parte do custo da reconstrução da Europa e do Japão, propiciando a queda comunismo e a ascensão da democracia no último quarto do século XX. Será o terrorismo uma ameaça forte o suficiente para impulsar um comportamento similar dos países desenvolvidos no início do século XXI? (Viola e Leis, 2001). Infelizmente as evidências do último ano não condizem com esta expectativa. Há uma tendência protecionista nos setores siderúrgico e agrícola nos Estados Unidos, pequena disponibilidade dos países desenvolvidos a negociar na OMC uma abertura plena de suas economias nos setores agrícola, têxtil e de calçados, justamente onde os países em desenvolvimento e pobres conseguem ser competitivos e, por fim, uma vitória na maior parte dos países europeus de candidatos orientados por uma agenda predominantemente defensiva com relação aos problemas globais.

\section{BIBLIOGRAFIA}

AGRAWALA, S. \& STEINAR A. (1999), "Indispensability and indefensibility: The United States in the climate treaty negotiations". Global Governance, 5 (2).

BROWN, L. C.; FLAVIN \& FRENCH, H. (2001), State of the world: a Worldwatch Institute Report on Progress toward a sustainable society. Nova York, Norton.

CASTELLS, M. (1996), The rise of the network society. Oxford, Blackwell Publishers.

CLARK, W.; VAN EIJNDOVEN, C. \& JAEGER, J. (eds.). (1998), Learning to manage global environmental risks: a comparative bistory of social responses to climate change, ozone depletion, and acid rain. Cambridge, MIT Press. 
CLAUSSEN, E. \& McNeilly, L. 1998), Equity \& global climate change: the complex elements of global fairness. Washington, Pew Center on Global Climate Change.

COOPER, R. (1998), "Toward a real global warming treaty". Foreign Affairs, 77 (2).

CHAYES, A \& HANDLER CHAYES, A. (1995), The new sovereignty: compliance with international regulatory agreements. Cambridge, Harvard University Press.

COMISSION ON GLOBAL GOVERNANCE. (1995), Our global neighborhood. Oxford, Oxford University Press.

GEHRING, T. (1994), Dynamic international regimes: Institutions for International environmental governance. Frankfurt am Main, Peter Lang.

GRUBB, M. (1999), The Kyoto Protocol: a guide and assessment. Londres, Royal Institute of International Affairs.

GUIDENS, A (1998), The Third Way: the renewal of social democracy. Cambridge, Polity Press.

GUIMARÃES, R. (1994), "Da oposição entre desenvolvimento e meio ambiente ao desenvolvimento sustentável: uma perspectiva do Sul", in Gelson Fonseca Jr. e Sergio Naburo de Castro (orgs.), Temas de política externa brasileira II, São Paulo, Paz e Terra.

HAAS, P. (ed.). (1997), Knowledge, power, and international policy coordination. Columbia, University of South Carolina Press.

HAAS, P. (1992), "Introduction: epistemic communities and international policy coordination”. International Organization, 46 (1).

HAAS, P.; KEOHANE, R. \& LEVY, M. (eds.). (1993), Institutions for the Earth: sources of effective environmental protection. Cambridge, MIT Press.

HURRELL, A. (1995), "International political theory and the global environment", in K. Boot e S. Smith (eds.), International relations theory today. Penn State University Press.
INGLEHART, R. (1997), Modernization and postmodernization: cultural, economic, and political change in 43 societies. Princeton, Princeton University Press.

JACOBY, H. \& PRIMM, R. (1998), “ Kyoto's unfinished business”. Foreign Affairs, 77 (4).

JAGUARIBE, H. (1996), "Brasil e o mundo na virada do século". Dados, 3 (39).

KAUL, I.; GRUNBERG, I. \& STERN, M. (orgs.). (1999), Global public goods. Oxford, Oxford University Press.

KECK, M. \& SIKKINK, K. (1998), Activists beyond borders: advocacy networks in international politics. Cornell University Press.

KEOHANE, R. (1983), "The demand for International Regimes", in S. Krasner (org.), International regimes, Nova York, Cornell University Press.

KEOHANE, R. \& Milner, H. (1996), Internationalization and domestic politics. Cambridge, Cambridge University Press.

KRASNER, S. (1983), "Structural causes and regime consequences: regimes as intervening variables", in S. Krasner (org.), International Regimes, Nova York, Cornell University Press.

LAFER, C. \& FONSECA JR., G. (1994), "Questões para a diplomacia no contexto internacional das polaridades indefinidas", in Gelson Fonseca Jr. e Sergio Naburo de Castro (orgs.), Temas de política externa brasileira II, São Paulo, Paz e Terra.

LIPPMAN, T. (2000), Madeleine Albright and the New American Diplomacy. Boulder, Westview Press.

MCCORMICK, J. (1989), Reclaiming paradise: the global environmental movement. Bloomington, Indiana University Press.

MILNER, H. (1997), Interests, institutions, and information: domestic politics and international relations. Princeton, Princeton University Press. 
MUELLER, B. (1999), Justice in global warming negotiations. Oxford, Oxford Institute for Energy Study.

NORTH, R. (1990), War, peace, survival: global politics and conceptual synthesis. Boulder, Westview Press.

NORHAUS, W. (1994), Managing the global commons: the economics of climate change. Cambridge, MIT Press.

O'RIORDAN, T. \& J. Jager (1996), Politics of climate change: a European perspective. Londres, Routledge.

PORTER, G \& BROWN, J. (1996), Global environmental politics. Boulder, Westview Press.

RISSE-KAPPEN, T. (1995), Bringing transnational relations back in: Non-state actors, domestic structures and international institutions. Cambridge, Cambridge University Press.

ROSENAU, J. (1997), Along the domestic-foreign frontier: exploring governance in a turbulent world. Cambridge, Cambridge University Press.

ROWLANDS, I. (1995), The politics of global atmospheric change. Manchester, Manchester University Press.

SAND, P. (ed.). (1992), The effectiveness of international environmental agreements. Cambridge, Grotius Publications Limited.

SCHELLING, T. (1997), "The Cost of combating global warming: facing the tradeoffs". Foreign Affairs, 76 (6).

SOROOS, M. (1997), The endangered atmosphere: preserving a global commons. Columbia, University of South Carolina Press.

STERN, P.; Young, O. \& Druckman, D. (eds.). (1992), Global environmental change: understanding the buman dimensions. Washington, National Academy Press.
VIOLA, E. (1997), "The environmental movement in Brazil: institutionalization, sustainable development and crisis of governance since 1987", in G. MacDonald, D. Nielson e M. Stern (eds.), Latin American environmental policy in international perspective. Boulder, Westview Press.

(1998), "Globalization, environmentalism and new transnational social forces", in C. Chung e B. Gillespie (orgs.), Globalization and the environment. Paris, OECD.

(1999), "A globalização da política ambiental no Brasil, 1990-1998", in D. Aguiar e J. Pinho (eds.), O agronegócio do Mercosul e a sua inserção na economia mundial, Anais do $37^{\circ}$ Congresso Brasileiro de Economia e Sociologia Rural, Brasília, Sober.

(2001), "É ainda viável o Protocolo de Kyoto depois do fracasso de Haia?". Carta Internacional, 97, mar.

VIOLA, E. \& LEIS, H. (2001), "Dilemas civilizatórios da globalização frente ao terrorismo fundamentalista”. Cena Internacional, 3 (2).

VOGLER, J. \& IMBER, M. (eds.), (1996), The environment and international relations. Londres, Routledge.

WASSON, M. (1997), Top soil and treaties: the politics of global change. Oxford, Oxford University Press.

WEISS BROWN, E. \& JACOBSON, H. (eds.), (1998), Engaging countries: strengthening compliance with international environmental accords. Cambridge, MIT Press.

YOUNG, O. (ed.). (1997), Global governance: drawing insights from the environmental experience. Cambridge, MIT Press. 


\section{O REGIME INTERNACIONAL THE INTERNATIONAL DE MUDANÇA CLIMÁTICA E O REGIME ON CLIMATE BRASIL}

\author{
Eduardo Viola
}

\section{Palavras-chave}

Políticas públicas, Protocolo de Kyoto, Acordo de Bonn, Acordo de Marrakesh, Mudança climática.

Eduardo Viola

\section{Keywords} The Bonn Agreement, The
Este artigo analisa o processo de formação do regime internacional de mudança climática desde as negociações e a assinatura da convenção Quadro das Nações Unidas sobre Mudança Climática, no Rio de Janeiro (1992), passando pela negociação e assinatura do Protocolo de Kyoto (1997), até a conclusão dos pontos pendentes do protocolo na VII Conferência das Partes em Marrakesh (2001). Também são estudados as políticas públicas relacionadas às emissões de carbono no Brasil, na década de 1990, e o posicionamento brasileiro em relação ao regime de mudança climática. No Protocolo de Kyoto (1996-2001), o Brasil propôs o Fundo de Desenvolvimento Limpo e opôs-se a compromissos de redução da taxa de crescimento futuro das emissões de gás carbono por parte dos países emergentes, ao estabelecimento de mecanismos flexibilizadores de mercado e à inclusão das emissões derivadas de mudança do uso da terra. Finalmente, analisam-se as perspectivas futuras do Protocolo de Kyoto depois dos Acordos de Bonn e Marrakesh, particularmente em relação à sua viabilidade a longo prazo sem a presença dos Estados Unidos.
Public Policies, The Kyoto Protocol, Marrakesh Agreement, Climatic Change

This article has three parts. In the first one the author analyses the formation of the international regime on climate change since the negotiations and signing of the United Nations Framework Convention on Climate Change (Rio de Janeiro, 1992), passing through the negotiations and signing of the Kyoto Protocol (1997), till the conclusion of the Protocol pending issues in the $7^{\text {th }}$ Conference of the Parts in Marrakech (2001). In the second part the author analyses the public policies related to carbon emissions in Brazil during the 1990s and the Brazilian standing in the climatechanging regime. The Brazilian standing in the negotiations of the Kyoto Protocol (1996-2001) was a combination of leadership and defensive positions: the proposal of the Clean Development Fund, opposition to commitments for the reduction of future growth rates in carbon emissions for emerging countries, initial opposition to the inclusion of market mechanisms for emissions reduction, and opposition to the inclusion of emissions derived from land use changes in the Protocol. In the third part the author analyses the future perspectives of the Kyoto Protocol after the Agreements in Bonn and Marrakech, particularly in relation to its long-term viability without the reentering of the United States.

\section{LE RÉGIME INTERNATIONAL DES CHANGEMENTS CLIMATIQUES ET LE BRÉSIL}

\author{
Eduardo Viola
}

\section{Mots-clés}

Politiques publiques, Protocole de Kyoto, Accord de Bonn, Accord de Marrakech, Changement climatique.

Cet article analyse le processus de formation du régime international des changements climatiques depuis les négociations et la signature de la Convention-cadre des Nations Unies sur les Changements Climatiques à Rio de Janeiro (1992), en passant par la négociation et la signature du Protocole de Kyoto (1997), jusqu'à la conclusion des questions pendantes du Protocole à la $\mathrm{VII}^{\mathrm{e}}$ Conférence des Parties à Marrakech (2001). Les politiques publiques relatives aux émissions de gaz carbonique au Brésil, dans les années 1990 et la position brésilienne para rapport que régime des changements climatiques, sont également analysées. Dans le Protocole de Kyoto (1996-2001), le Brésil a proposé la création d'un Fonds de Développement Propre et s'est opposé à des compromis de réduction de la taxe de croissance future des émissions de gaz carbonique par rapport aux pays en développement, à l'établissement de mécanismes de flexibilisation du marché et à l'inclusion des émissions issues du changement de l'usage de la terre. Finalement, l'auteur analyse les perspectives futures du Protocole de Kyoto depuis les Accords de Bonn et de Marrakech, particulièrement par rapport à sa viabilité à long terme sans la présence des États-Unis. 